\title{
Dimensional analysis of milk fat globules in sow milk: effects of the lactation stage and fat content and comparison with vaccine milk
}

\author{
M. Faustini • C. Colombani • D. Vigo • R. Communod • \\ V. Russo • T. Chlapanidas • E. Munari • A. Morandotti • \\ M. L. Torre
}

Published online: 12 May 2010

(C) Springer Science+Business Media B.V. 2010

\begin{abstract}
To assess the differences in the granulometry of milk fat globules between swine and bovine species, milk samples from 30 lactating sows were analyzed for fat globule dimensions and compared with cow milk samples. Results showed differences between the fat globules: sow milk presents reduced globule diameters compared with cow milk (volume-weighted diameter 2.62 vs. $3.27 \mu \mathrm{m}, p<0.001$ ) and reduced interglobular distance. A positive relationship was observed between milk fat content and globule diameter, while a slight, insignificant inverse trend was detected between the day of lactation and fat globule diameter. These complex interactions between milk lipids, globule membrane proteins, and globule dimensions provide a better understanding of digestion/absorption phenomena in the design of milk replacers.
\end{abstract}

Keywords Sow $\cdot$ Milk $\cdot$ Fat globule $\cdot$ Granulometry
Abbreviations
MFG milk fat globules
MID mean interglobular distance

\section{Introduction}

Physical and colloidal properties of milk are pivotal in the determination of a number of milk characteristics in toto (color, texture, fat surfacing, etc.) (Huppertz and Kelly 2006). In

M. Faustini $\cdot$ C. Colombani $\cdot$ D. Vigo $\cdot$ R. Communod $\cdot$ V. Russo $\cdot$ E. Munari $\cdot$ A. Morandotti Dipartimento di Scienze e Tecnologie Veterinarie per la Sicurezza Alimentare, Università degli Studi, Milano, Italy

T. Chlapanidas $\cdot$ M. L. Torre

Dipartimento di Chimica Farmaceutica, Università degli Studi, Pavia, Italy

M. Faustini $(\bowtie)$

Department of Veterinary Sciences and Technologies for Food Safety-Faculty of Veterinary Medicine, University of Milan, via G. Celoria, 10, 20133 Milan, Italy

e-mail: Massimo.faustini@unimi.it 
the last decade, the determination of dimensional parameters of the milk fat globules (MFG), mainly in bovine milk, has become popular since the texture and sensorial characteristics of milk and its derived products are heavily influenced by MFG dimensions (Michalski et al. 2003; Michalski et al. 2007). Michalski et al. (2005a, b) pointed out a relationship between MFG dimensions and the digestive characteristics of its lipid components. The characteristics of the MFG geometric properties have been extensively studied in cows (Walstra et al. 1969; Van Boekel and Folkerts 1991; Attaie and Richter 2000; Lopez 2005) and other mammals, including goats (Mehaia 1995; Attaie and Richter 2000), camels (Mehaia 1995; Farah and Ruegg 1991), sheep (Mehaia 1995; Gervilla et al. 2001), and humans (Ruegg and Blanc 1981; Michalski et al. 2005a, b). Sow's milk has received some attention in terms of its composition (Klobasa et al. 1987; Csapó et al. 1996; Alston-Mills et al. 2000), but the scientific literature lacks any data about the dimensional distribution of MFG. The aim of the present work was to analyze the dimensional distribution of MFG in the sow through laser light scatter analysis, comparing the results with vaccine milk.

\section{Materials and methods}

A total of 30 lactating sows were enrolled. Each milk sample (at least $5 \mathrm{~mL}$ ) was collected from three nipples (anterior, median, and posterior) in the morning hours. Specimens were preserved in glass tubes at $4{ }^{\circ} \mathrm{C}$ until analysis was performed (within $12 \mathrm{~h}$ of collection). Fat content in each of the samples was determined (Romeu-Nadal et al. 2004). Milk samples had a mean fat content of $8.33 \pm 4.42(\mathrm{w} / \mathrm{w})$, with a median value of $6.74 \%(\mathrm{w} / \mathrm{w})$. The dimensional characteristics of sow MFG were compared with standard native milk (e.g., bovine milk). Granulometric evaluation of MFG for the samples was performed using a Coulter Beckman LS230 laser scatter granulometer. Milk samples were put drop-wise into the measurement cell; $1.25 \mathrm{~mL}$ of $35 \mathrm{mM}$ Na-EDTA buffer at $\mathrm{pH} 7.0$ were added prior to each determination to assure disruption of casein micelles (Lopez 2005). Samples were evaluated for modal diameter (mode, $\mu \mathrm{m})$, surface-weighted diameter $\left(\mathrm{d}_{\mathrm{s}}, \mu \mathrm{m}\right)$, volume-weighted diameter

Table 1 Descriptive statistics for the dimensional parameters of milk fat globules in sow and cow milk.

\begin{tabular}{|c|c|c|c|c|c|c|c|c|}
\hline \multirow[t]{2}{*}{ Variable } & \multicolumn{4}{|c|}{ Sow milk } & \multicolumn{4}{|c|}{ Bovine milk } \\
\hline & Med & 25 th & 75 th & Mean \pm sd & Med & 25 th & 75 th & Mean \pm sd \\
\hline Mode $(\mu \mathrm{m})^{\mathrm{a}}$ & $2.31 *$ & 2.10 & 2.79 & $2.52 \pm 0.92$ & 3.06 & 3.06 & 3.44 & $3.29 \pm 0.55$ \\
\hline $\mathrm{d}_{\mathrm{s}}(\mu \mathrm{m})^{\mathrm{a}}$ & $2.04 *$ & 1.89 & 2.32 & $2.05 \pm 0.35$ & 2.66 & 2.48 & 2.80 & $2.61 \pm 0.26$ \\
\hline $\mathrm{d}_{\mathrm{v}}(\mu \mathrm{m})$ & $2.62 *$ & 2.43 & 2.92 & $2.93 \pm 1.20$ & 3.27 & 3.04 & 3.65 & $3.54 \pm 0.94$ \\
\hline $\mathrm{SSA}\left(\mathrm{cm}^{2} / \mathrm{mL}\right)^{\mathrm{a}}$ & $29395^{*}$ & 25869 & 31757 & $30168 \pm 6187$ & 22549 & 21427 & 24195 & $23195 \pm 2449$ \\
\hline $\mathrm{d} 10(\mu \mathrm{m})$ & $1.28 *$ & 1.02 & 1.42 & $1.23 \pm 0.25$ & 1.54 & 1.49 & 1.61 & $1.55 \pm 0.11$ \\
\hline $\mathrm{d} 50(\mu \mathrm{m})^{\mathrm{a}}$ & $2.44^{*}$ & 2.16 & 2.66 & $2.46 \pm 0.61$ & 3.02 & 2.86 & 3.26 & $3.06 \pm 0.43$ \\
\hline $\mathrm{d} 90(\mu \mathrm{m})^{\mathrm{a}}$ & $4.39 *$ & 3.83 & 5.06 & $5.22 \pm 3.05$ & 5.27 & 4.92 & 5.87 & $5.94 \pm 2.70$ \\
\hline $\operatorname{Span}^{\mathrm{a}}$ & 1.23 & 1.44 & 1.53 & $1.60 \pm 0.97$ & 1.23 & 1.19 & 1.35 & $1.39 \pm 0.59$ \\
\hline $\operatorname{Igd}(\mu \mathrm{m})^{\mathrm{a}}$ & 4.39 & 2.38 & 7.48 & $5.05 \pm 2.60$ & n.d. & & & \\
\hline
\end{tabular}

n.d.- not determined

${ }^{\text {a }}$ non-normal distribution (Martinez-Iglewicz test, both species)

*Differences with $p<0.001$ between median values (Kruskal-Wallis test) 
$\left(d_{v}, \mu \mathrm{m}\right)$, specific surface area $\left(\mathrm{SSA}, \mathrm{cm}^{2} / \mathrm{mL}\right)$, the 10th, 50th, and 90th $(\mu \mathrm{m})$ percentiles of $d_{v}$ distribution, and a span index [span, $\mu \mathrm{m}$, a dimensionless index of diameter dispersion, calculated as $\left.(\mathrm{d} 90-\mathrm{d} 10) / \mathrm{d} 50^{*} 100\right]$. In milk sow samples, the mean interglobular distance (MID) was determined, calculated as follows: $\left.\operatorname{MID}(\mu \mathrm{m})=0.225 \mathrm{~d}_{\mathrm{s}} \cdot[(74 / \varphi)-1)\right]$ where $\phi$ is the milk sample fat percentage (Walstra et al 1969). Datasets were checked for normality, and the differences between porcine and bovine milk were evaluated by the non-parametric test of Kruskal and Wallis. The relationship between the most representative dimensional parameter $\left(\mathrm{d}_{\mathrm{v}}\right)$, the day of lactation (day), and the milk fat percentage ( fat $)$ was determined by Huber robust multiple linear regression analysis.

\section{Results}

The descriptive statistics for the dimensional parameters of the MFG from the two groups of subjects are reported in Table 1.

Results indicated that all of the variables except for span index, the MFG diameter was statistically reduced when compared to bovine milk $(p<0.001)$. Differences are particularly noteworthy for $d_{v}, d 50$, and $d 90$. The SSA was also augmented ( $+30.4 \%$ on average). Sow milk showed a median MID of $6.98 \mu \mathrm{m}$ and a range of $1.71-8.85 \mu \mathrm{m}$; these values were reduced with respect to bovine milk as reported by Abeni et al. (2005) (21.1-22.3 $\mu \mathrm{m})$. Huber robust regression analysis, using the equation $\mathrm{d}_{\mathrm{v}}=2.122-0.034$ day $+0.103 \mathrm{fat}$, where day is for the lactation day and fat is the $(\mathrm{w} / \mathrm{w})$ fat percentage, highlighted a significant effect of the equation's $y$ intercept $(p<0.001)$ and lipid percentage $(p<0.05)$, but not of lactation day, on $\mathrm{d}_{\mathrm{v}}$.

\section{Discussion}

Fat globules show clear interspecific differences not only in terms of composition but also of dimension. In the present study, great differences between bovines and porcines were observed. In sow milk, MFG are differently dispersed, as highlighted by the MID values, with reduced diameters, offering a higher attack surface with respect to bovine milk. MFG diameter increases with fat content, while an inverse relationship, although not significant, was observed between globular diameter and lactation day. These observations can help achieve a better understanding of the relationships between fat globule dimensions, lipid composition, and nutritional characteristics of milk. MFG can be seen as lipoproteic complexes with micro/nano-particle characteristics (Argov et al. 2008) that influence the processes of release and absorption in the gut. A deeper integration of information about these phenomena could lead to the design of milk replacements with ad hoc particle characteristics to tailor this precious food to the needs of piglets.

\section{References}

Abeni F, Degano L, Calza F, Giangiacomo R, Pirlo G (2005) Milk quality and automatic milking: Fat globule size, natural creaming and lipolysis. J Dairy Sci 88:3519-3529

Alston-Mills B, Iverson SJ, Thomson MP (2000) A comparison of the composition of milks from Meishan and crossbred pigs. Livest Prod Sci 63:85-91

Argov N, Lemay DG, German JB (2008) Milk fat globule structure and function: Nanoscience comes to milk production. Trends Food Sci Technol 19:617-623

Attaie R, Richter RL (2000) Size distribution of fat globules in goat milk. J Dairy Sci 83:940-944 
Csapó J, Martin TG, Csapo-Kiss ZS, Hazas Z (1996) Protein, fats, vitamin and mineral concentrations in porcine colostrum and milk from parturition to 60 days. Int Dairy J 6:881-902

Farah Z, Ruegg M (1991) The creaming properties and size distribution of fat globules in camel milk. J Dairy Sci 74:2901-2904

Gervilla R, Ferragut V, Guamis B (2001) High hydrostatic pressure effect on color and milk-fat globule of ew's milk. J Food Sci 66:880-885

Huppertz T, Kelly AL (2006). Physical chemistry of milk fat globules. In: Fox PF and McSweeney PLH (eds) Advanced Dairy Chemistry, Vol. 2: Lipids, 3rd edn. Springer, New York, pp 173-212

Klobasa F, Werhahn E, Butler JE (1987) Composition of sow milk during lactation. J Anim Sci 64:1458-1466

Lopez C (2005) Focus on the supramolecular structure of milk fat in dairy products. Reprod Nutr Dev 45:497-511

Mehaia MA (1995) The fat globule size distribution in camel, goat, ewe and cow milk. Milchwissenschaft 50:260-263

Michalski MC, Gassi JY, Famelart MH, Leconte N, Camier B, Michel F, Briard V (2003) The size of native milk fat globules affects physico-chemical and sensory properties of Camembert cheese. Lait 83:131-143

Michalski MC, Briard V, Desage M, Geloen A (2005a) The dispersion state of milk fat influences triglyceride metabolism in the rat-a 13 CO2 breath test study. Eur J Nutr 44:436-444

Michalski MC, Briard V, Michel F, Tasson F, Poulain P (2005b) Size distribution of fat globules in human colostrums, breast milk and infant formula. J Dairy Sci 88:1927-1940.

Michalski MC, Camier B, Gassi JY, Briard-Bion V, Leconte N, Famelart MH, Lopez C (2007) Functionality of smaller vs. control native milk fat globules in Emmental cheeses manufactured with adapted technologies. Food Nutr Res 40:191-202

Romeu-Nadal M, Morera-Pons S, Castellote AI, Lòpez-Sabater MC (2004) Comparison of two methods for the extraction of fat from human milk. Anal Chim Acta 513:457-461

Ruegg M, Blanc B (1981) The fat globule size distribution in human milk. Biochim Biophys Acta 66 :7-14

Van Boekel MAJS, Folkerts T (1991) Effect of heat treatment on the stability of milk fat globules. Milchwissenschaft 46:758-765

Walstra P, Oortwin H, de Graaf J (1969) Studies on milk fat dispersion. Methods for determining globule-size distribution. Neth Milk Dairy J 23:12-36 